\title{
Glucocorticoids inhibit the apoptotic actions of UV-C but not Fas ligand in hepatoma cells: direct evidence for a critical role of $\mathrm{Bcl}-\mathbf{x}_{\mathrm{L}}$
}

\author{
AB Scoltock ${ }^{1}$, G Heimlich $^{1}$ and JA Cidlowski ${ }^{\star 1}$
}

Our laboratory has shown that glucocorticoids can inhibit apoptosis in rat hepatoma cells; however, the mechanisms are incompletely understood. To address this issue we sought to determine if glucocorticoid inhibition is effective when death is induced by stimuli that more selectively activate either the intrinsic (UV-C) or extrinsic (FasL) apoptotic pathways. Using flow cytometric analysis, we show that pretreatment of HTC cells with dexamethasone (Dex) inhibits UV-C- but not FasL-induced apoptosis. This inhibition requires Dex pretreatment and can be abrogated by the glucocorticoid antagonist RU486 indicating glucocorticoid receptor-mediated action. Dex increases anti-apoptotic $B c l-x_{L}$ at both $m R N A$ and protein levels. The $B c l-x_{L}$ protein level remains elevated even after apoptosis induction with either UV-C or FasL although only UV-C-induced cell death is inhibited. Repression of Bcl- $\mathrm{x}_{\mathrm{L}}$ protein with siRNA abrogates the anti-apoptotic effect of glucocorticoids. Together these data provide direct evidence that $B c l-x_{L}$ mediates glucocorticoid inhibition of UV-C induced apoptosis.

Cell Death and Differentiation (2007) 14, 840-850. doi:10.1038/sj.cdd.4402071; published online 15 December 2006

Apoptosis is a highly regulated physiological process of cell death that is necessary for proper development and maintenance of an organism. This regulation is carried out in part by a balance in the synthesis and degradation of pro- and antiapoptotic factors that determine cell fate. Disturbances in this process are the basis for various disease states including cancer, neurodegenerative diseases such as Alzheimer's and auto-immune diseases including lupus and diabetes. Mutations or changes in expression levels of pro- or anti-apoptotic proteins are also often associated with malignant transformation. ${ }^{1}$ As multiple changes can exist in the apoptotic machinery in one type of malignant cell, cancer chemotherapy regimens often employ a combination of drugs each with a different mechanism of inducing cell death. One class of drugs widely used in cancer treatment is the glucocorticoids. They are used as direct cell death-inducers in lymphomas and leukemias. ${ }^{2}$ Glucocorticoids are also often given in conjunction with other chemotherapies to ameliorate side effects of the primary drugs or to reduce edema. Although primarily recognized for their apoptotic stimulating actions on $T$ lymphocytes, reports have suggested that glucocorticoids can inhibit apoptosis in several cell types including glioma and astrocytoma cell lines, ${ }^{3}$ fibroblasts, ${ }^{4,5}$ gastric cancer cell lines, mammary epithelial cells, ${ }^{6,7}$ hepatoma cells ${ }^{8}$ and glomerular endothelial cells. ${ }^{9}$ Previous studies from our laboratory have shown that glucocorticoids can inhibit serum-deprivation induced apoptosis in hepatoma cells ${ }^{10}$ but the mechanisms underlying this action are largely undefined. Specific inhibition of cancer cell apoptosis would obviously not be the desired effect of an adjunct chemotherapy. Thus, fully understanding how glucocorticoids inhibit apoptosis in cancer cells is of the utmost importance. In particular, we wanted to further delineate the mechanisms of the inhibitory effects of glucocorticoids on apoptosis that has been induced via the extrinsic or intrinsic apoptotic pathway.

Current research on apoptotic signaling mechanisms primarily supports the idea of two caspase-dependent pathways leading to programmed cell death. ${ }^{11}$ The first involves the death receptor or extrinsic pathway which is initiated by TNF-receptor family members that recruit adaptor and signaling molecules to assemble the death-inducing signaling complex (DISC). This complex leads to rapid activation of caspases 8 and/or 10, which then activate downstream effector caspases such as caspase 3,6 and $7 .^{12,13}$ Caspase 8 can also cleave the pro-apoptotic protein Bid to form tBid and this truncated form of Bid translocates to the mitochondrial membrane to trigger the cell death process and may form an amplification loop for the death receptor pathway. ${ }^{14,15}$ In contrast, the intrinsic pathway for apoptosis is activated by various cellular stress stimuli, including UV irradiation (for a review see Fumarola and Guidotti ${ }^{16}$ ). In this pathway, the mitochondria appear to be the primary target for the deathinducing stress response. These organelles undergo a loss of mitochondrial membrane potential $\left(\Delta \Psi_{\text {mito }}\right)$ and release several apoptotic proteins including cytochrome $c$, which participates in the formation of the apoptosome together with Apaf- 1 to activate caspase 9. This pathway is subject to regulation by $\mathrm{Bcl}-2$ family members. ${ }^{17-20}$ This intrinsic path-

\footnotetext{
${ }^{1}$ Laboratory of Signal Transduction, National Institute of Environmental Health Sciences, National Institutes of Health, Department of Health and Human Services, Research Triangle Park, NC, USA

*Corresponding author: JA Cidlowski, Laboratory of Signal Transduction, National Institute of Environmental Health Sciences, National Institutes of Health, 111 TW Alexander Dr., Research Triangle Park, NC 27709, USA. Tel: + 1919541 1564; Fax + 1919541 1367; E-mail: cidlows1 @ niehs.nih.gov Keywords: apoptosis; UV-C; Fas ligand; Bcl-- $\mathrm{L}_{\mathrm{L}}$; glucocorticoids Abbreviations: $\Delta \Psi_{\text {mito, }}$, mitochondrial membrane potential; FasL, fas ligand; Dex, dexamethasone; AFU, arbitrary fluorescence units Received 01.2.06; revised 29.9.06; accepted 27.10.06; Edited by PH Krammer; published online 15.12.06
} 
way converges at later stages of the apoptotic process with the extrinsic pathway on downstream effectors of cell death. ${ }^{21,22}$

Glucocorticoids are now recognized to inhibit apoptosis in some cells but the mechanism of inhibition induced by glucocorticoids has not been fully elucidated, although a role for the anti-apoptotic Bcl-2 family proteins has been suggested in mammary tumor cells and leukemia cells. For example increases in $\mathrm{Bcl}-\mathrm{x}_{\mathrm{L}} \mathrm{mRNA}$ occur in leukemia cells ${ }^{23}$ and in mammary epithelial cells ${ }^{6}$ treated with dexamethasone. Promoter analysis in heterologous expression systems suggest that glucocorticoid response elements exist in one of the Bcl-x gene's promoters. ${ }^{24}$ Additionally, it has been recently shown that dexamethasone induces $\mathrm{Bcl}-\mathrm{x}_{\mathrm{L}}$ transcription during fibrosarcoma tumor growth. ${ }^{25}$ However, data has been largely correlative and do not provide direct evidence for $\mathrm{Bcl}-\mathrm{x}_{\mathrm{L}}$ 's glucocorticoid regulated anti-apoptotic effects

In the current investigation, we demonstrate that dexamethasone can protect the rat hepatoma cell line, HTC, from UV-C but not FasL-induced apoptosis. Dexamethasone pretreatment causes a receptor-dependent increase in both $\mathrm{Bcl}-\mathrm{x}_{\mathrm{L}} \mathrm{mRNA}$ and protein. Interestingly, the level of $\mathrm{Bcl}-\mathrm{x}_{\mathrm{L}}$ protein remains elevated during treatment irrespective of the apoptosis inducer. Inhibition of the dexamethasone-induced increase in $\mathrm{BCl}-\mathrm{x}_{\mathrm{L}}$ protein by concurrent treatment with the antagonist RU486 abolishes the anti-apoptotic effect of glucocorticoids on UV-C induced cell death. In addition, when the endogenous levels of $\mathrm{Bcl}-\mathrm{x}_{\mathrm{L}}$ are reduced by siRNA, the hepatoma cells are prone to spontaneous apoptosis without additional apoptotic stimuli and Dex has no anti-apoptotic effect on these cells. These data suggest that $\mathrm{Bcl}-\mathrm{x}_{\mathrm{L}}$ is a primary component of the underlying mechanism of glucocorticoid-induced inhibition of apoptosis.

\section{Results}

UV-C irradiation or FasL induce apoptosis in HTC cells. The rat hepatoma cell line HTC will undergo apoptosis induced by serum/growth factor deprivation ${ }^{10}$ but the cell death response induced by other stimuli has not been extensively studied. Here, we examined the ability of other stimuli to induce apoptosis in HTC cells namely UV-C irradiation which signals primarily via the intrinsic or mitochondrial pathway ${ }^{26}$ or FasL which activates the death receptor or extrinsic pathway. ${ }^{12}$ HTC cells were left untreated, treated with either $50 \mathrm{ng} / \mathrm{ml}$ FasL or irradiated with $90 \mathrm{~mJ} / \mathrm{cm}^{2}$ UV-C light. After $24 \mathrm{~h}$ the cells were trypsinized, centrifuged, resuspended in media, loaded with the appropriate dye and then examined by flow cytometry.

Both UV-C and FasL treatments resulted in the appearance of populations of cells with classic apoptotic characteristics after $24 \mathrm{~h}$ (Figure 1). Untreated cells display a single population on a forward scatter versus side scatter plot indicating a normal cell size. Cells treated with either UV-C or FasL show cells of normal size and cells with decreased forward scatter indicating cell shrinkage, a hallmark of apoptotic cell death (Figure 1, first row). We also evaluated mitochondrial membrane potential depolarization (loss of $\left.\Delta \Psi_{\text {mito }}\right)$, another indicator of apoptotic cell death, which can be monitored utilizing the mitochondrial membrane potential sensitive dye JC-1. Mitochondria from normal cells take up the dye in aggregate form, which emits fluorescence in the orange range $(\sim 580 \mathrm{~nm})$; however, when mitochondria become depolarized the dye reverts to a monomeric form which emits fluorescence in the green range $(\sim 520 \mathrm{~nm})$. Untreated HTC cells show mainly a single population with high aggregate (orange) fluorescence indicating cells with functional mitochondria and normal $\Delta \Psi_{\text {mito }}$. Cells treated with either FasL or UV-C display the normal population but also a dramatic increase in a second population with decreased aggregate (red) but increased monomer (green) fluorescence indicating cells with mitochondria which show a loss of $\Delta \Psi_{\text {mito }}$ (Figure 1, second row). Another classical hallmark of apoptosis is DNA degradation. Using ethanol fixation and the DNA intercalating dye propidium iodide, we analyzed the DNA degradation following apoptosis induction. Untreated HTC cells show a large G1/G0 peak (at approximately 400 arbitrary fluorescence units) with a smaller G2/M peak (approximately 800 AFU) and very few cells (less than 10\%) in the subdiploid range (less than $400 \mathrm{AFU}$ ). Cells induced to undergo apoptosis with either FasL or UV-C show an increase in the number of cells with subdiploid DNA (Figure 1, third row). These results reveal that HTC cells undergo classical apoptosis at $24 \mathrm{~h}$ post-stimuli with these doses of FasL and UV-C.

Dexamethasone pre-treatment protects HTC cells from UV-C induced but not FasL-induced apoptosis. After establishing that HTC cells undergo classic apoptosis when induced by UV-C or FasL, we next examined if pretreatment with glucocorticoids could inhibit cell death. Previous studies from our lab have shown that HTC cells required a $24 \mathrm{~h}$ glucocorticoid pretreatment for maximal inhibition against serum deprivation induced apoptosis. ${ }^{10}$ As the UV-C and FasL pathways could have different kinetics than serum deprivation cells were treated with or without $10 \mathrm{nM}$ Dex for 4 , 8,16 or $24 \mathrm{~h}$. The cells were then left untreated or treated with FasL $50 \mathrm{ng} / \mathrm{ml}$ or $90 \mathrm{~mJ} / \mathrm{cm}^{2}$ UV-C, which yields comparable induction of apoptosis and percentages of cells with apoptotic features were determined by flow cytometry as described in Figure 1. In addition, treated and non-treated cells were examined by confocal microscopy to determine if the cells had morphologic features of apoptosis. Consistent with the data in Figure 1 both apoptotic inducers alone caused an increase in the population of cells with loss of cell size, decreased $\Delta \Psi_{\text {mito }}$, and degraded DNA (Figure 2a). Dex pretreatment followed by induction of apoptosis with FasL did not prevent the appearance of apoptotic cell populations as determined by flow cytometry; specifically cell shrinkage, loss of $\Delta \Psi_{\text {mito }}$, and DNA degradation (Figure 2a). In contrast Dex pretreated cells followed by UV-C irradiation showed less cell shrinkage, changes in $\Delta \Psi_{\text {mito }}$, and DNA degradation with the greatest inhibition seen at pretreatment times of 16 and $24 \mathrm{~h}$ (Figure 2a). Visually FasL- and UV-C-treated cells displayed typical apoptotic morphology, namely shrinkage and blebbing of the plasma membrane as opposed to untreated cells and cells treated with Dex alone (Figure 2b). Pretreatment with Dex inhibits the appearance of apoptotic morphology in UV-C-treated cells, however, there is no inhibition in FasL-treated cells (Figure 2b). 
Control

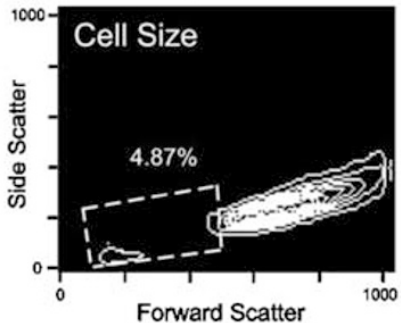

Forward Scatter
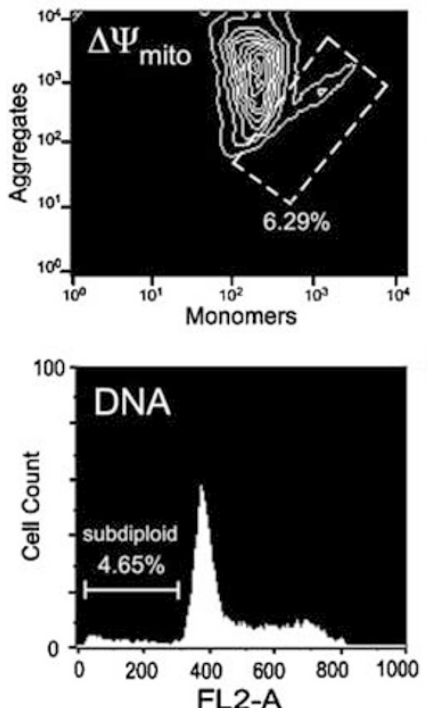

UV-C

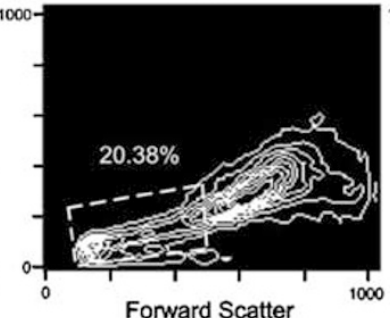

Forward Scatter
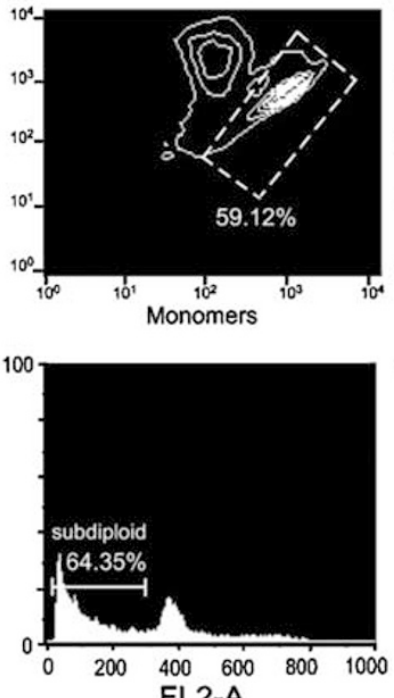

FasL
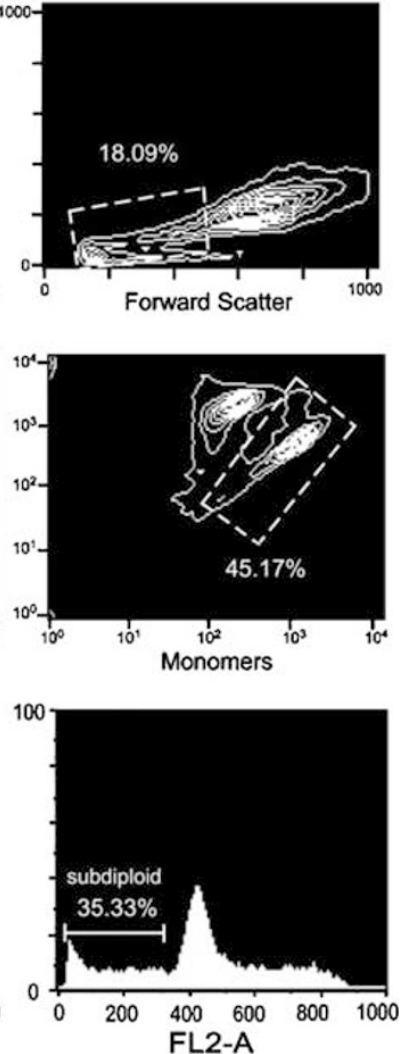

Figure 1 UV-C or FasL induce features of apoptosis in HTC Cells. HTC cells were left untreated, treated with either $50 \mathrm{ng} / \mathrm{ml}$ FasL or irradiated with $90 \mathrm{~mJ} / \mathrm{cm}^{2} \mathrm{UV}$-C. After $24 \mathrm{~h}$ the cells were trypsinized, centrifuged, brought up in media (to a final concentration of 0.5 to $1 \times 10^{6} \mathrm{celll} / \mathrm{m} / \mathrm{m}$ ) plus the appropriate dye and examined by flow cytometry (see Materials and Methods). Both UV-C and FasL treatments induce the appearance of populations of cells with apoptotic characteristics after $24 \mathrm{~h}$. Shown in the figure are representative flow cytometry plots of three separate experiments: loss of cell size (forward scatter versus side scatter), loss of $\Delta \Psi_{\text {mito }}$ (monomers versus aggregates), and DNA degradation (arbitrary fluorescence units versus cell number)

Western blot analysis demonstrates that caspase 3 is cleaved in the FasL- and UV-C-treated cells (Figure 2c). Pretreatment with Dex blocks caspase 3 cleavage in UV-C but not FasL treated cells (Figure $2 \mathrm{c}$ ). These results suggest that glucocorticoid treatment is selectively affecting the signaling of the intrinsic apoptotic pathway. Based on knowledge of glucocorticoid receptor (GR) action and the requirement for long term steroid pretreatment suggests that receptor dependent gene induction is likely involved in the anti-apoptotic effect of glucocorticoid.

Anti-apoptotic effects of Dex are blocked by RU486. To determine if the anti-apoptotic effects of Dex treatment were GR-dependent the selective glucocorticoid antagonist,
RU486 was evaluated for its ability to block the action of GR. As Dex had no inhibitory effect on FasL-induced apoptosis the effects of pretreatment with Dex and RU486 were analyzed in UV-C treated cells. Consistent with previous findings the percentage of shrunken cells, cells with loss of $\Delta \Psi_{\text {mito }}$ and cells with subdiploid DNA were increased by UV-C irradiation while either Dex or RU486 alone in unstimulated cells had no effect (Figure 3 ). The percentage of cells in these apoptotic populations after UV-C irradiation was decreased by Dex pretreatment (Figure 3). The anti-apoptotic effects of Dex pretreatment could be blocked by concurrent treatment with $100 \mathrm{nM}$ RU486 indicating action via the glucocorticoid receptor (Figure 3). The fact that Dex pretreatment was anti-apoptotic only when

Figure 2 Dex pretreatment inhibits UV-C-induced but not FasL-induced apoptosis. Cells were treated with FasL $50 \mathrm{ng} / \mathrm{ml}$ or $90 \mathrm{~mJ} / \mathrm{cm}^{2} \mathrm{UV}-\mathrm{C}$ and percentages of cells with apoptotic features were determined from at least three separate experiments or the cells were treated and visualized by microscopy in three experiments. (a) Cells were pretreated with Dex for $4,8,16$ or $24 \mathrm{~h}$ before apoptosis induction. Both UV-C and FasL caused an increase in the population of cells with loss of cell size, and decreased $\Delta \Psi_{\text {mito }}$, and degraded DNA. Pretreatment with Dex for 16 and $24 \mathrm{~h}$ significantly decreased $(P<0.01)$ these apoptotic populations in UV-C irradiated cells but had no inhibitory effect on FasL-treated cells. (b) Cells left untreated or treated with Dex alone show similar morphology. Cells treated with FasL or UV-C show apoptotic morphology namely cell shrinkage and membrane blebbing. Cells treated with Dex + FasL still show apoptotic morphology while cells treated with Dex + UV-C are protected. (c) Protein lysates of treated or untreated cells were analyzed by Western blot for the presence of cleaved caspase 3. Both FasL and UV-C treatment cause caspase 3 cleavage while Dex pretreatment prevented caspase 3 cleavage in UV-C but not FasL-treated cells 
a
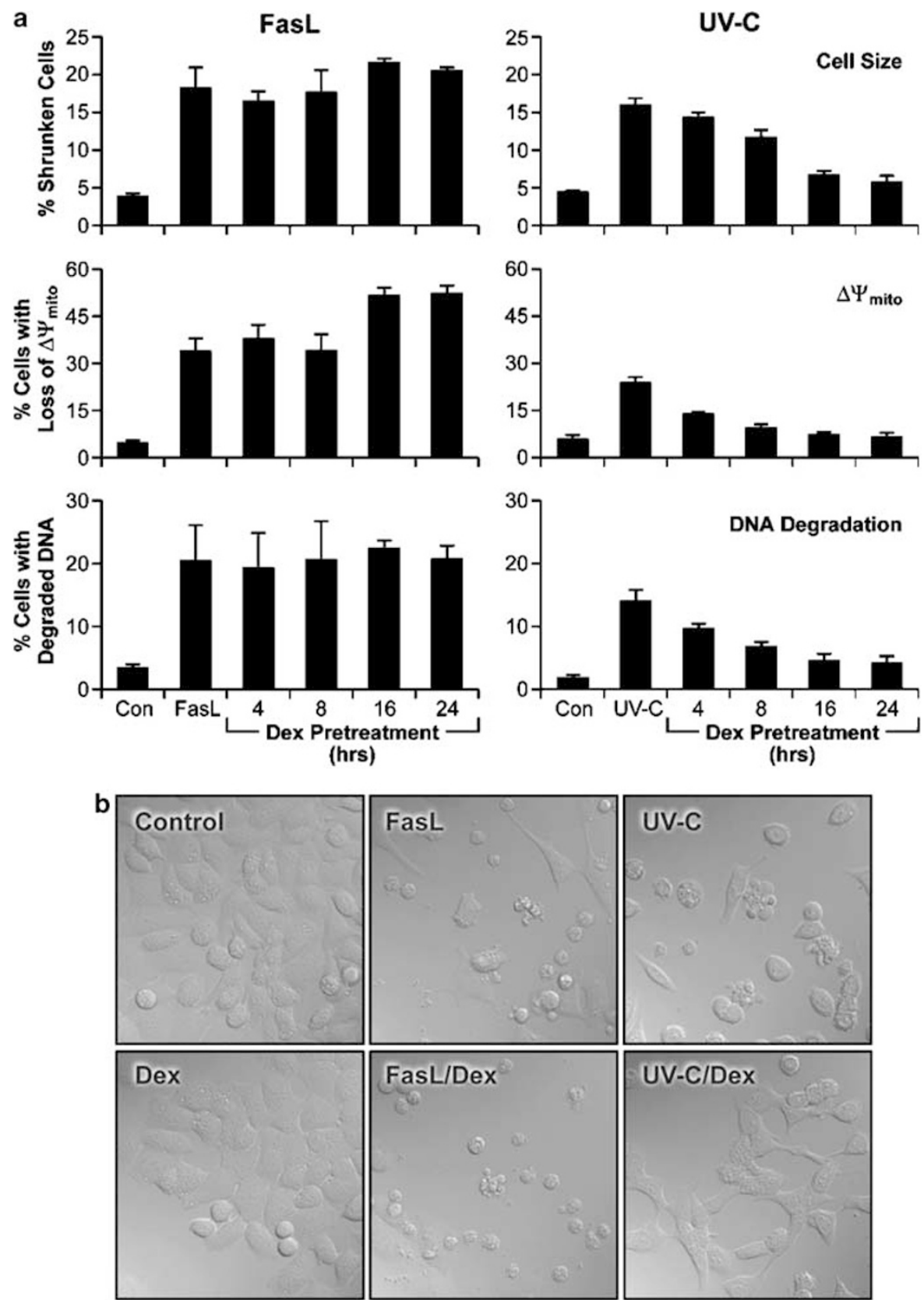

C

Fas ligand

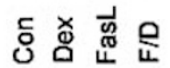

UV-C

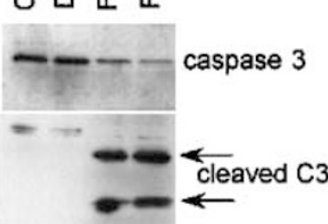

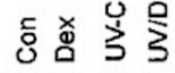

$--=-$ caspase 3

$-\leftarrow$ cleaved C3

actin 

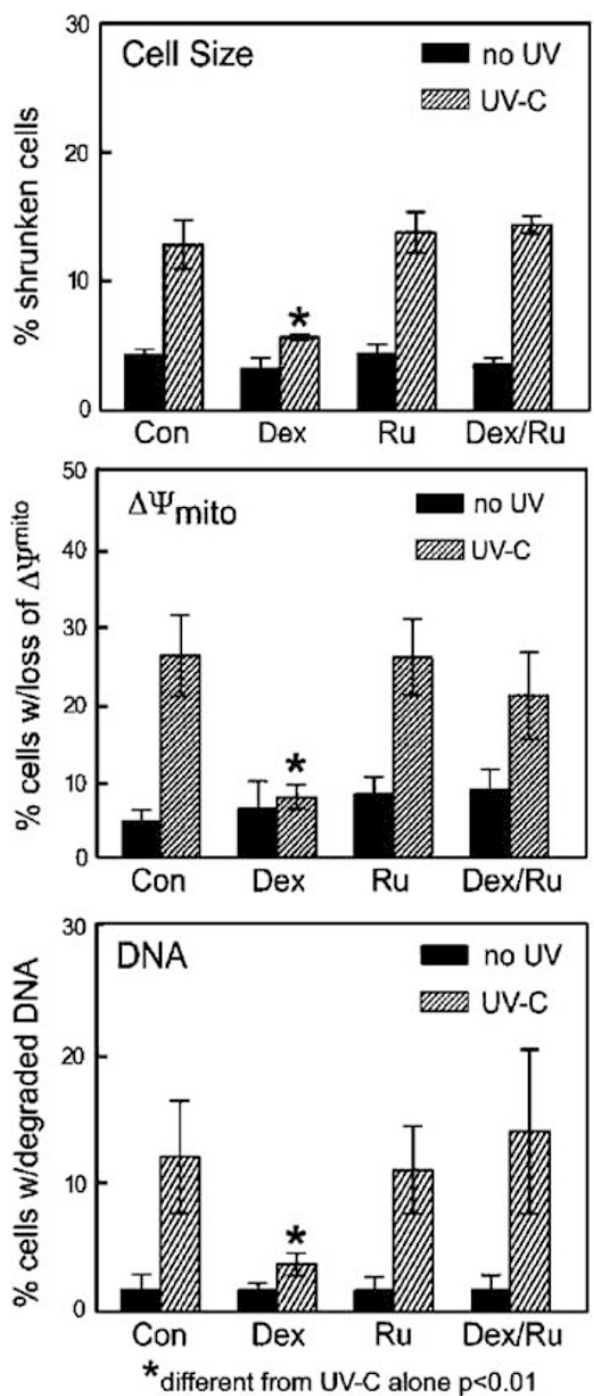

Figure 3 Inhibition of UV-C-induced apoptosis by Dex blocked by coadministration of RU486. HTC cells were left untreated or treated with $10 \mathrm{nM}$ Dex, $100 \mathrm{nM}$ RU486, a glucocorticoid antagonist, or a combination of both $24 \mathrm{~h}$ before UV-C irradiation. UV-C caused an increase in the population of cells with loss of cell size, decreased $\Delta \Psi_{\text {mito, }}$, and degraded DNA. Pretreatment with Dex significantly $(P<0.01)$ decreased these apoptotic populations. RU486 alone had no effect. Co-treatment of Dex with RU486 inhibits Dex effects against UV-C. The results are averages \pm S.E.M. of at least three separate experiments

cell death was induced by the intrinsic pathway suggested the possibility of transcriptional regulation of $\mathrm{Bcl}-2$ family members which are critical for this apoptosis pathway.

Dex treatment causes an increase in Bcl- $x_{L}$ mRNA and protein. To determine if $\mathrm{Bcl}-2$ family members were involved in the anti-apoptotic effects of Dex, we initially examined HTC cells for changes in Bim, Bid, Bcl-2 and Bcl- $\mathrm{X}_{\mathrm{L}}$ mRNA after Dex treatment using real-time PCR. Bim and Bid mRNA were present but not affected by Dex treatment. Although the Bcl-2 mRNA was detected, it was at the very limit of the analysis and was not affected by Dex treatment (data not shown). In contrast, the mRNA for Bcl- $\mathrm{x}_{\mathrm{L}}$ was increased at 8 and $16 \mathrm{~h}$ after Dex treatment and remained elevated more than twofold at $24 \mathrm{~h}$. This induction of $\mathrm{Bcl}-\mathrm{x}_{\mathrm{L}}$ mRNA was abrogated by co-treatment with RU486 (Figure 4b).

We further examined other Bcl-2 family members' protein levels in HTC cells. As shown in Figure 4a the anti-apoptotic protein $\mathrm{Mcl}-1$ and the proapoptotic proteins Bax and Bid were not affected by Dex treatment, though UV-C caused a decrease in Mcl-1 and Bid proteins. However, reflecting the increase in mRNA seen in Figure $4 \mathrm{a}, \mathrm{Bcl}-\mathrm{x}_{\mathrm{L}}$ protein showed a Dex-induced increase (Figure 4a). Western blot analysis of whole cell lysates at $4,8,16$ and $24 \mathrm{~h}$ after Dex treatment showed that $\mathrm{BCl}-\mathrm{X}_{\mathrm{L}}$ protein increased in a time dependent manner with the maximal induction being at 16 and $24 \mathrm{~h}$ (Figure 4c). This increase in protein could also be blocked by co-treatment of the cells with RU486 (Figure 4d).

Dex-induced increase in $\mathrm{Bcl}-\mathrm{x}_{\mathrm{L}}$ protein is sustained during apoptosis induction: $\mathrm{Bcl}-\mathrm{x}_{\mathrm{L}}$ remains associated with mitochondria. To determine whether the increase in $\mathrm{Bcl}-\mathrm{x}_{\mathrm{L}}$ protein was responsible for the anti-apoptotic effects of Dex treatment, we examined the protein levels before and after UV-C treatment. While UV-C treatment alone decreased $\mathrm{BCl}-\mathrm{X}_{\mathrm{L}}$ protein levels, protein levels remained elevated during UV-C following Dex pretreatment (Figure 5a). Interestingly, the protein also remained elevated during FasL treatment although it apparently afforded no anti-apoptotic actions on the extrinsic pathway of apoptosis induced by FasL (Figure 5a). Together these results, in addition to our results demonstrating that cotreatment with RU486 can block the inhibitory effects of Dex on UV-C-induced apoptosis, suggest that the increase in $\mathrm{Bcl}-\mathrm{x}_{\mathrm{L}}$ protein is responsible for the anti-apoptotic actions of glucocorticoid treatment when the apoptotic pathway is activated by UV-C.

Current research suggests that Bcl-2 family members exert their effects primarily at the mitochondria. ${ }^{19}$ To determine if the $\mathrm{BCl}-\mathrm{x}_{\mathrm{L}}$ protein properly translocates in HTC cells, we examined whether the increased $\mathrm{Bcl}-\mathrm{x}_{\mathrm{L}}$ protein was associated primarily with the cytosolic or mitochondrial compartments. HTC cells treated with or without Dex and then with or without UV-C irradiation were subjected to subcellular protein fractionation; a Dex-induced increase in $\mathrm{Bcl}-\mathrm{x}_{\mathrm{L}}$ protein was detected by Western blot in both the cytosolic and mitochondrial fractions (Figure $5 b$ ). This increase in $\mathrm{Bcl}-\mathrm{X}_{\mathrm{L}}$ was preserved in the mitochondrial fraction after UV-C irradiation while in the cytosolic fraction $\mathrm{Bcl}-\mathrm{X}_{\mathrm{L}}$ protein was decreased (Figure $5 b$ ). Interestingly, $\mathrm{Bcl}-\mathrm{x}_{\mathrm{L}}$ protein remaining elevated in the mitochondrial fraction even after UV-C irradiation supports the idea that the increase in $\mathrm{Bcl}-\mathrm{x}_{\mathrm{L}}$ protein is correlated with the anti-apoptotic effects of Dex treatment.

Dex is a synthetic glucocorticoid that has been reported to bind using high doses to the drug metabolizing receptor PXR as well as the glucocorticoid receptor. As PXR actions have been reported to affect the expression of Bcl-2 family members, ${ }^{27}$ we investigated whether our results could be recapitulated using the naturally occurring glucocorticoids cortisol and corticosterone which do not bind PXR. Using the same pretreatment times $(24 \mathrm{~h})$ and the same dose of UV-C irradiation $\left(90 \mathrm{~mJ} / \mathrm{cm}^{2}\right) \mathrm{Bcl}-\mathrm{x}_{\mathrm{L}}$ protein levels were analyzed in cells treated with these hormones. These steroids also 
a
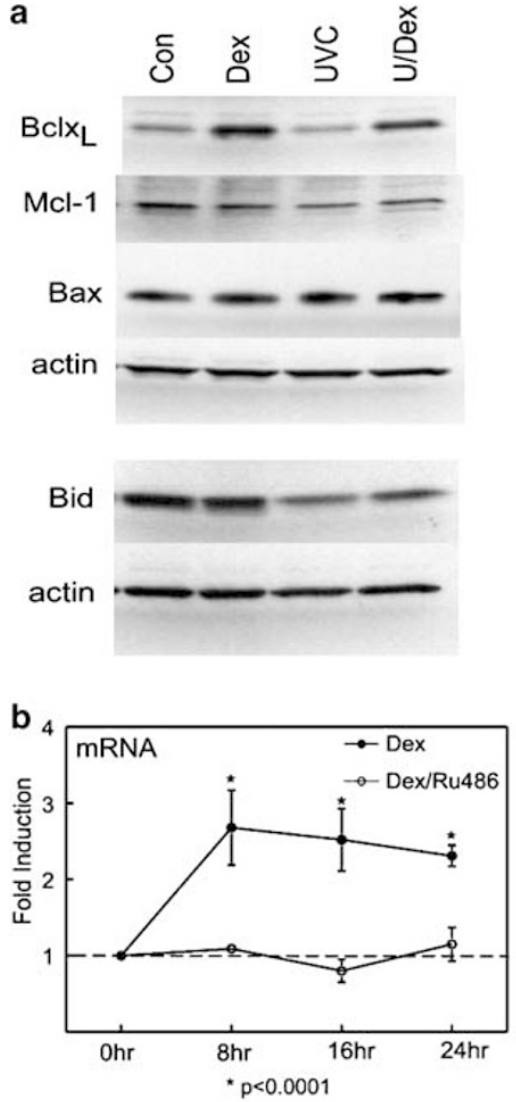

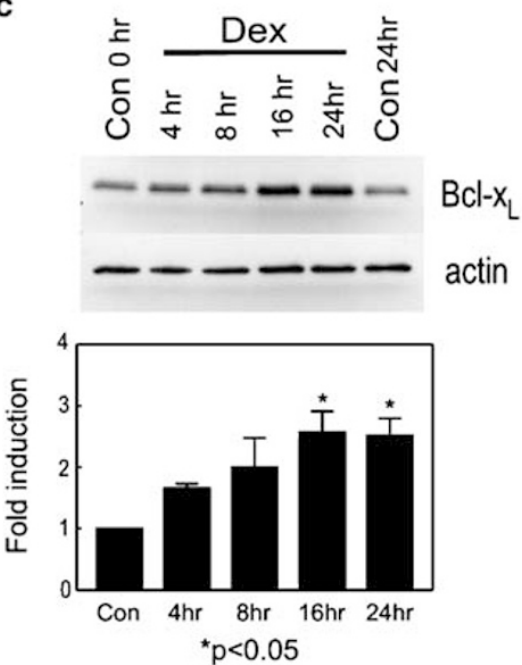

d

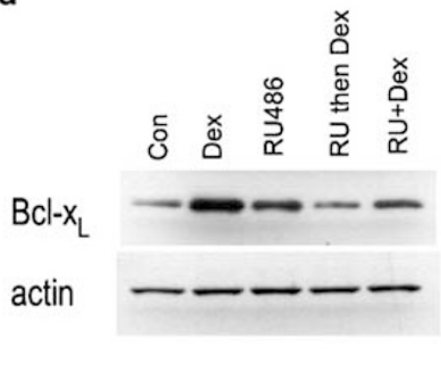

Figure 4 Dex induces Bcl-xL mRNA and protein in HTC cells. (a) HTC cells were treated with or without Dex then left untreated or irradiated with UV-C. Protein lysates were analyzed by Western blotting for Bcl- $x_{L}, \mathrm{Mcl}-1$, Bax, Bid and actin (loading control). (b) HTC cells were treated with Dex or treated with Dex + RU486 for $0,8,16$ and $24 \mathrm{~h}$

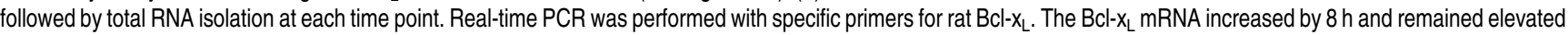
at $24 \mathrm{~h}$. This increase was blocked by RU486. The results are averages \pm S.E.M. of at least three separate experiments. (c) Cell lysates were assayed by western blot for presence of Bcl-xL protein 1. Representative Western blot of time course 2. Fold induction of Bcl-xL protein was determined by densitometry and plotted as averages \pm S.E.M. of at least three experiments. (d) The Dex-induced increase in protein can be inhibited by co-administration of the antagonist RU486 and reduced to control levels by pretreatment with RU486

induced an increase in $\mathrm{Bcl}-\mathrm{x}_{\mathrm{L}}$ protein (Figure $5 \mathrm{c}$ ). These results show that the increase in $\mathrm{Bcl}-\mathrm{x}_{\mathrm{L}}$ is not restricted to the synthetic glucocorticoid, Dex, but can be regulated by the natural glucocorticoids corticosterone and cortisol found in rats and humans, respectively.

siRNA knockdown of $\mathrm{Bcl}-\mathrm{x}_{\mathrm{L}}$ protein. Even though Dex increases $\mathrm{Bcl}-\mathrm{x}_{\mathrm{L}}$ at the mRNA and protein level and these increases can be blocked by the antagonist RU486, there may be other apoptosis related genes affected by glucocorticoid receptor signaling. To test if the Dex-induced increase in $\mathrm{Bcl}-\mathrm{x}_{\mathrm{L}}$ protein is the primary cause of the antiapoptotic action of glucocorticoids on UV-C-induced apoptosis, we used small interfering RNA's (siRNA) to decrease transcription of the $\mathrm{Bcl}-\mathrm{x}_{\mathrm{L}}$ gene and thus decrease the protein levels. Transfection of a random siRNA control (BLAST-searched to have no known homology to any gene sequence) did not interfere with the Dex induced increase in $\mathrm{Bcl}-\mathrm{x}_{\mathrm{L}}$ protein. However, using siRNA sequences generated specifically for rat $B c l-x_{L}$, we decreased the induced levels of $B c l-x_{L}$ protein as well as the endogenous levels (Figure 6). After transfecting siRNA to $\mathrm{Bcl}-\mathrm{x}_{\mathrm{L}}$, treating with or without Dex, we demonstrate that the
Dex-induced increase in protein is repressed (Figure 6). The data show this method can be used to repress $\mathrm{Bcl}-\mathrm{x}_{\mathrm{L}}$ protein specifically in HTC cells thus allowing us to examine the consequences on the anti-apoptotic effects of Dex.

Decreased $\mathrm{Bcl}-\mathrm{x}_{\mathrm{L}}$ levels abrogate the anti-apoptotic effect of glucocorticoids. Using this siRNA system to decrease the $\mathrm{Bcl}-\mathrm{x}_{\mathrm{L}}$ protein in HTC cells, we returned to our original experimental paradigm to determine if Dex pretreatment was still anti-apoptotic in cells which had reduced levels of $\mathrm{BCl}-\mathrm{x}_{\mathrm{L}}$ as a result of siRNA treatment. Cells were transfected with $10,20,50$ or $100 \mathrm{nM}$ siRNA or non-specific RNA and incubated for $24 \mathrm{~h}$, Dex treated for an additional $24 \mathrm{~h}$, then UV-C irradiated. After a subsequent $24 \mathrm{~h}$ they were analyzed for apoptotic characteristics.

Apoptotic volume decrease. Cells left untransfected or transfected with non-specific RNA display an increased population of shrunken cells after UV-C-irradiation (measured by forward scatter light as in Figure 1) and this population is decreased by pretreatment with Dex (Figure 7a). Cells transfected with siRNA to $\mathrm{Bcl}-\mathrm{x}_{\mathrm{L}}$ show a dose-dependent relief of Dex-inhibition. Interestingly, the knock down of $\mathrm{Bcl}-\mathrm{x}_{\mathrm{L}}$ to less than endogenous levels (which 
a
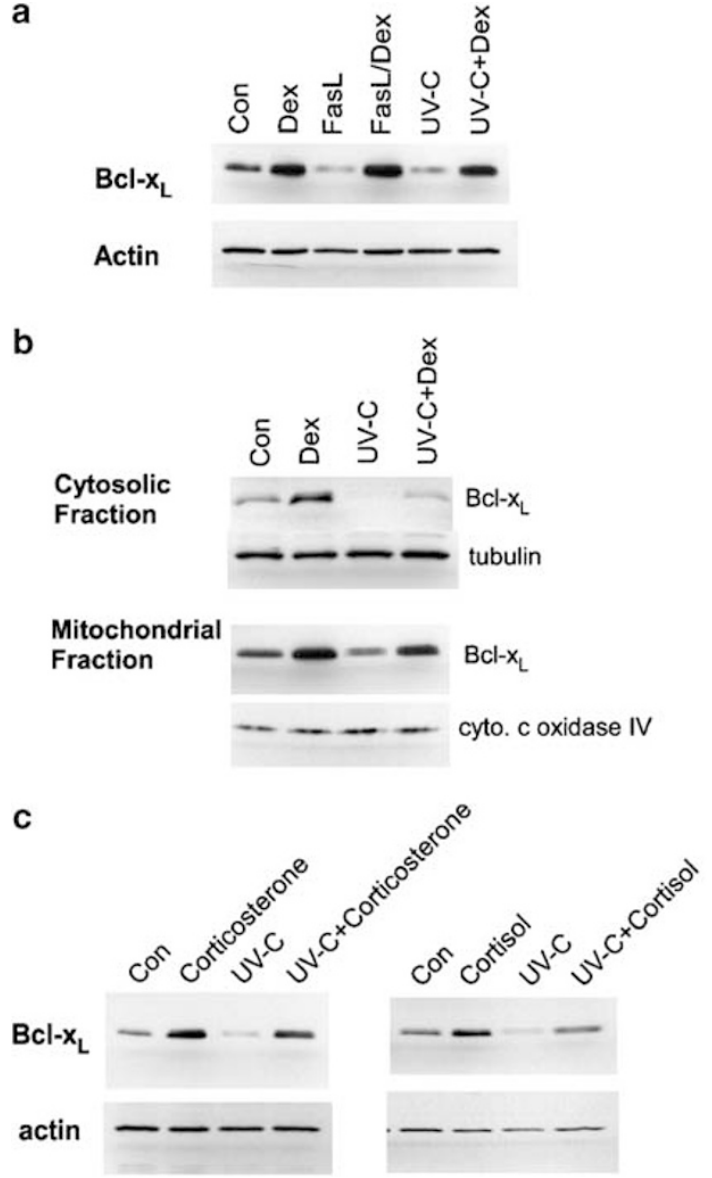

Figure 5 (a) Dex-induced increase in Bcl-xL protein is sustained during FasL or UV-C treatment. HTC cells were treated with Dex, FasL, UV-C, Dex + FasL or Dex + UV-C and lysates assayed for $\mathrm{BCl}-\mathrm{X}_{\mathrm{L}}$ protein by Western blot. Bcl- $\mathrm{x}_{\mathrm{L}}$ protein remains elevated in the Dex-pretreated cells regardless of apoptotic stimulus. Shown is a representative blot from at least three separate experiments. (b) Bcl-xL remains elevated in the mitochondrial compartment after UV-C treatment. HTC cells were pretreated with Dex and then UV-irradiated. A subcellular fractionation was performed to obtain cytosolic and mitochondrial fractions. Each fraction was assayed by western blot for $\mathrm{Bcl}-\mathrm{x}_{\mathrm{L}}$. Tubulin was used as loading control for cytosol and cytochrome $c$ oxidase subunit IV used with the mitochondrial fraction. Dex caused an increase in Bcl- $x_{L}$ in both cytosolic and mitochondrial compartments. The protein levels remained elevated in the mitochondrial fraction even after UV-C irradiation. Shown are representative western blots from at least three separate experiments. (c) Effects of Dex can be recapitulated with naturally occurring glucocorticoids. HTC cells were pretreated with either $10 \mathrm{nM}$ cortisol or corticosterone for $24 \mathrm{~h}$ and then UV-irradiated. $24 \mathrm{~h}$ postradiation the cells were harvested for protein and assayed by Western blot for $\mathrm{Bcl}-\mathrm{x}_{\mathrm{L}}$ protein. Both glucocorticoids caused an increase in $\mathrm{Bcl}-\mathrm{x}_{\mathrm{L}}$, which remained elevated even after UV-C irradiation

occurs with 50 and $100 \mathrm{nM}$ siRNA, see Figure 6) causes the appearance of shrunken cells in the non-UV irradiated group (Figure 7a).

Loss of $\Delta \Psi_{\text {mito. Non-transfected cells or cells transfected }}$ with non-specific siRNA show a population of cells with mitochondria showing a loss of $\Delta \Psi_{\text {mito }}$ after UV-C irradiation. The anti-apoptotic effects of Dex are observed in both non-transfected and non-specific RNA transfected cells (Figure 7b). Cells transfected with increasing amounts of siRNA to Bcl- $\mathrm{X}_{\mathrm{L}}$ show a dose-dependent inhibition of the

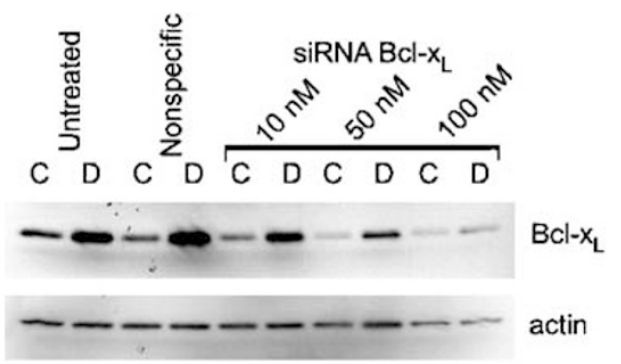

Fold repression of Dex-induced increase in $\mathrm{Bcl}-\mathrm{x}_{\mathrm{L}}$ protein

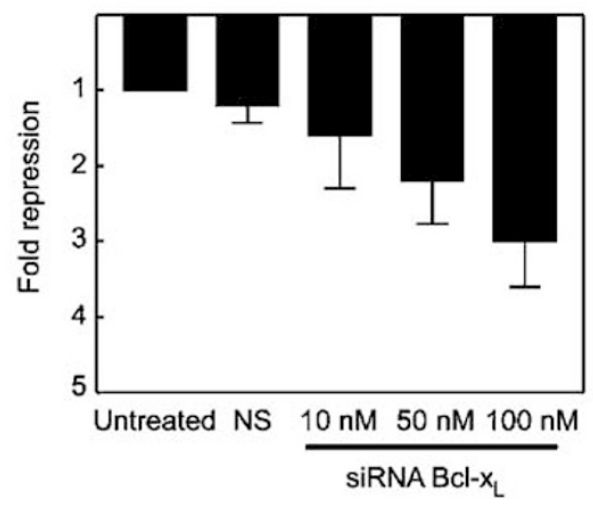

Figure 6 siRNA knockdown of Bcl-xL protein. HTC cells were transfected with increasing amounts of siRNA to $\mathrm{Bcl}-\mathrm{x}_{\mathrm{L}}$, a non-specific RNA or left untransfected. $24 \mathrm{~h}$ later the cells were harvested and analyzed by Western blotting. The highest amount of siRNA (100 nM) decreased the level of induced as well as endogenous $\mathrm{Bcl}-\mathrm{x}_{\mathrm{L}}$ protein. Fold repression was plotted as averages \pm S.E.M. of at least three separate experiments

anti-apoptotic effects of Dex. As seen with cell shrinkage reduction of endogenous levels of $\mathrm{Bcl}-\mathrm{x}_{\mathrm{L}}$ protein causes the loss of $\Delta \Psi_{\text {mito }}$ in non-irradiated cells suggesting that constitutive expression of $\mathrm{Bcl}-\mathrm{x}_{\mathrm{L}}$ has a function in maintaining cellular viability in these hepatoma cells.

DNA degradation. Non-transfected cells or cells transfected with non-specific siRNA show a population of cells with subdiploid or degraded DNA after UV-C irradiation. The number of cells with degraded DNA is decreased by pretreatment with Dex (Figure 7c). Cells transfected with siRNA to Bcl- $\mathrm{X}_{\mathrm{L}}$ no longer show an anti-apoptotic effect of Dex pretreatment (Figure 7c). However, as with cell shrinkage and loss of $\Delta \Psi_{\text {mito }}$, knockdown of endogenous $\mathrm{Bcl}-\mathrm{x}_{\mathrm{L}}$ protein causes DNA degradation without additional apoptotic stimulus. These results support the premise that the increase in $\mathrm{Bcl}-$ $\mathrm{X}_{\mathrm{L}}$ protein is primarily responsible for the anti-apoptotic actions of Dex. Interestingly, the appearance of apoptotic characteristics in non-UV-C-treated cells in which the endogenous $\mathrm{BCl}-\mathrm{x}_{\mathrm{L}}$ has been reduced suggests that this hepatoma cell line requires endogenous levels of $B c l-x_{L}$ to maintain viability.

\section{Discussion}

Dexamethasone acting via the glucocorticoid receptor can have many, quite often opposing effects depending on the cell type, state of differentiation or phase of the cell cycle. Glucocorticoids can induce apoptosis in thymocytes and other cells of lymphoid origin; where in other cell types these 
hormones can be anti-apoptotic. This seeming contradiction can be at least partially explained by the fact that the glucocorticoid receptor has many proposed mechanisms of action such as direct transcriptional activation by specific responsive elements or more indirect repressive mechanisms via interference with other transcription factors such as AP-1 and $N F K B$. It is interesting to note that glucocorticoids have even been reported to have opposing effects on the same gene depending on the cell type. For example the Bcl-x gene
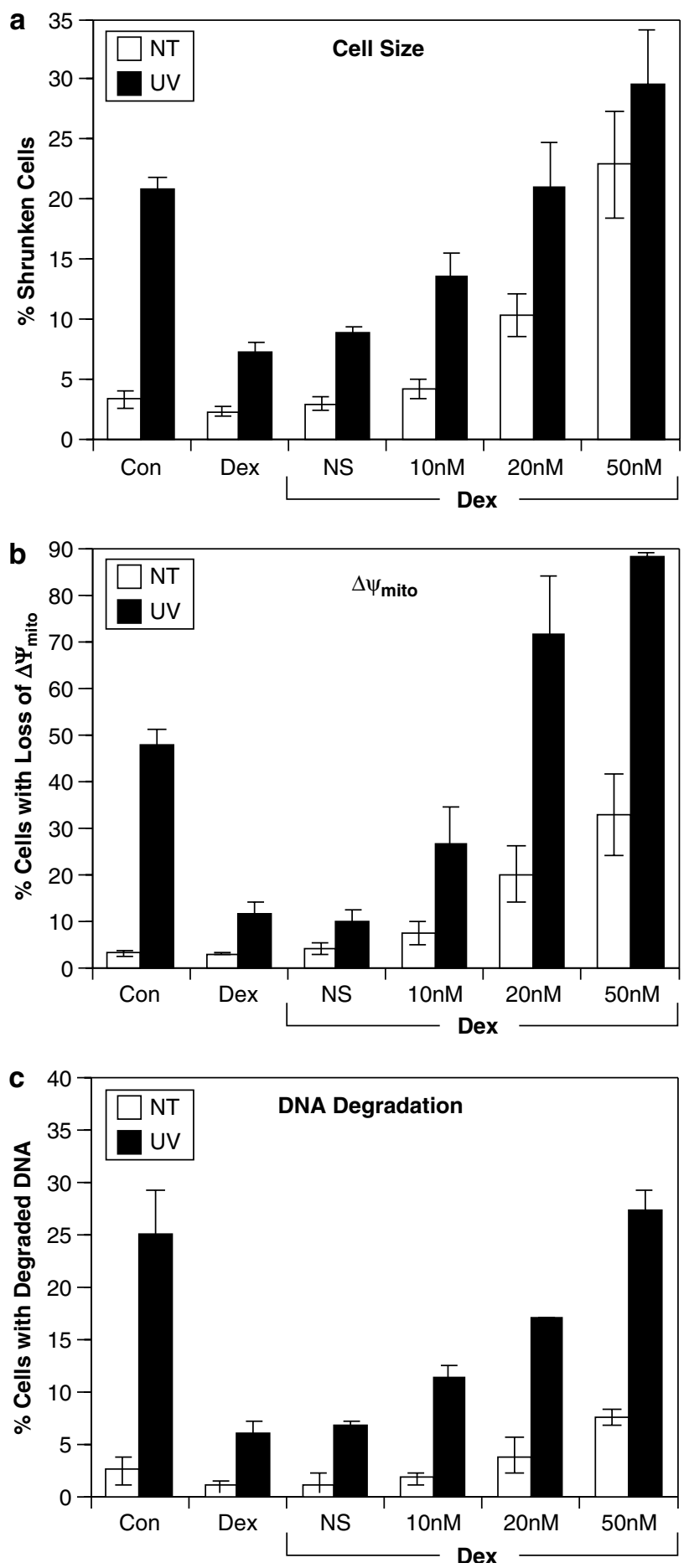

was reported to be downregulated by dexamethasone in rat thymocytes which die in response to Dex, ${ }^{28}$ but upregulated in mouse fibrosarcoma cells. ${ }^{25}$ Interestingly, the mouse $\mathrm{Bcl}-\mathrm{x}$ gene has been reported to have five different promoters which exhibit a tissue-specific pattern of promoter usage. ${ }^{29}$ This is a possible explanation of the differing effects of glucocorticoids on apoptosis in cells of lymphoid and non-lymphoid origin. While the induction of the Bcl- $x_{L}$ mRNA in mammary epithelial and fibrosarcoma cells has been reported there are several other examples of anti-apoptotic actions of glucocorticoids that do not involve the regulation of $B C l-x_{L}$ such as the upregulation of serum and GC-inducible protein kinase-1 $(\mathrm{SGK}-1)^{30}$ and mitogen-activated protein kinase phosphatase-1 (MKP-1). ${ }^{31}$ In addition, dexamethasone alone ${ }^{32}$ or in conjunction with TNF-alpha can induce the cellular inhibitor of apoptosis-2 (c-IAP2) gene. ${ }^{33}$ Thus the precise mechanism for the anti-apoptotic effects of glucocorticoids remains unclear.

In the present study, we wished to further delineate the mechanism of the anti-apoptotic effect of Dex on the rat hepatoma cell line, HTC. We show in conjunction with our previously reported studies that Dex can protect HTC cells from apoptosis induced by stimuli that affect primarily the intrinsic or mitochondrial pathway (UV-irradiation) but not from apoptosis induced solely via the extrinsic pathway (FasL). We also demonstrate that the anti-apoptotic protein $\mathrm{Bcl}-\mathrm{x}_{\mathrm{L}}$ is upregulated at the mRNA and protein level by glucocorticoids in a receptor and time dependent manner, which coincides with pretreatment times necessary for anti-apoptotic actions of glucocorticoids. Interestingly, the $\mathrm{Bcl}-\mathrm{x}_{\mathrm{L}}$ protein remains elevated in the mitochondrial compartment even during UV-treatment. When this increase in $\mathrm{Bcl}-\mathrm{x}_{\mathrm{L}}$ is abrogated by cotreatment with RU486 or gene knockdown with siRNA there is no longer an inhibition of UV-C-induced apoptosis providing direct evidence for its role in mediating the anti-apoptotic effects of glucocorticoids. These results are also in agreement with current research which states that $\mathrm{Bcl}-\mathrm{x}_{\mathrm{L}}$ exerts its protective effects at the mitochondrial membrane and so would be expected to act on the intrinsic apoptotic pathway (for review Chan and $\mathrm{Yu}^{34}$ ). In contrast, the extrinsic or death receptor pathway can bypass mitochondrial signaling through direct activation of caspase 3 by caspase $8^{13,15}$ thus it is not surprising that increased levels of $\mathrm{Bcl}-\mathrm{x}_{\mathrm{L}}$ would not provide significant protection in this scenario. Interestingly, our results differ from $\mathrm{On}$ et $\mathrm{a}^{\beta 5}$ who recently reported that primary

Figure 7 Knockdown of Bcl-xL: effects on cell shrinkage, changes in $\Delta \Psi_{\text {mito, }}$, DNA degradation. HTC cells were transfected with $10,20,50$ or $100 \mathrm{nM}$ siRNA to $\mathrm{BCl}-\mathrm{x}_{\mathrm{L}}$ or a non-specific RNA. At $24 \mathrm{~h}$ later they were treated with Dex for $24 \mathrm{~h}$ followed by UV-C irradiation. After a final $24 \mathrm{~h}$ incubation the cells were harvested and assayed by flow cytometry. Results from at least three different experiments were averaged and displayed as percentage of shrunken cells for untreated, Dex treated, UV-C irradiated and Dex + UV-C. (a) UV-C causes the appearance of a population of shrunken cells. This population is decreased by pretreatment with Dex. Knockdown of Bcl- $\chi_{\llcorner}$protein dose dependently abrogates the effect of Dex. (b) UV-C causes the appearance of a population of cells with depolarized $\Delta \Psi_{\text {mito }}$. This population is decreased by pretreatment with Dex and this decrease is abrogated by knockdown of Bcl- $x_{L}$ protein. (c) UV-C causes the appearance of a population of cells with degraded (subdiploid) DNA. Pretreatment with Dex inhibits this population. Knockdown of $\mathrm{Bcl}-\mathrm{x}_{\mathrm{L}}$ protein abrogates this effect 
hepatocytes could be protected from Fas ligand induced apoptosis by large doses of dexamethasone $(5 \mu \mathrm{M})$ via upregulation of cFLIP. We attempted to reproduce their results in our hepatoma cells, however, we found no antiapoptotic effects of Dex either with physiological doses (Figure 2) or the higher dose used by Oh et al (data not shown). It would be of great interest to see if their results could be recapitulated with naturally occurring glucocorticoids since high doses of Dex are known to activate PXR. Additionally we did not detect any cFLIP protein in HTC cells (data not shown). This finding plus the fact of differing cell types - normal versus cancer cell - provides a possible explanation of the differences and does not negate the significance of our finding that a widely used class of pharmaceuticals can inhibit apoptosis in certain cancer cells. Indeed there is a clinical study by Herr et $\left.a\right|^{\beta 6}$ reporting glucocorticoid's protective effect on solid tumors. Another clinical study by Sui et $a \beta^{\beta 7}$ demonstrates that glucocorticoids interfere with paclitaxel treatment of breast and ovarian xenograft tumors. There is a study reporting that the non-steroidal antibiotic rifampicin can protect Jurkat cells from Fas ligand induced apoptosis presumably via the glucocorticoid receptor. ${ }^{38}$ Whether rifampicin is actually working through the GR is controversial, ${ }^{39}$ however Jurkat cells are reported to be type II cells which require a mitochondrial amplification loop via Bid for effective death receptor killing. Upregulation of $\mathrm{Bcl}-\mathrm{x}_{\mathrm{L}}$ (which they report as well as upregulation of cFLIP and $\mathrm{Bcl}-2$ ) in this instance might be expected to protect Jurkat cells from Fas ligand-induced apoptosis.

Another interesting finding in this study was that suppression of the endogenous levels of $\mathrm{Bcl}-\mathrm{X}_{\mathrm{L}}$ in these cells via siRNA knockdown sensitized them to cell death whereas transfection of a nonspecific RNA had no significant effect on viability. This data suggests that these hepatoma cells must utilize increased endogenous levels of $\mathrm{Bcl}-\mathrm{x}_{\mathrm{L}}$ as a growth or survival advantage during transformation. This scenario for cancer cells has been described by Takehara et $a{ }^{40}$ in HepG2 cells where repression of $\mathrm{Bcl}-\mathrm{x}_{\mathrm{L}}$ protein sensitized them to stress-induced apoptosis.

The fact that glucocorticoids are a highly prescribed class of pharmaceuticals, understanding the effects of these hormones on apoptosis is vitally important for proper treatment of inflammatory disease and cancer. Not only are glucocorticoids given as chemotherapeutics in leukemias - where they are well-known to induce apoptosis - they are also given as adjunct therapy in other types of cancers to relieve side effects of chemotherapy. There is emerging evidence that glucocorticoids can have inhibitory effects on treatment of nonlymphoma/leukemic cancers. ${ }^{36}$ In view of the data presented here and elsewhere we suggest their use as adjunct therapy be re-evaluated.

\footnotetext{
Materials and Methods

Cell Culture and steroid treatment. The HTC rat hepatoma cell line (originally derived from the Morris $7288 \mathrm{c}$ hepatoma) was the generous gift of $\mathrm{Dr}$ Stoney Simons (NIDDK, NIH). HTC cells were cultured in DMEM-H medium containing $5 \%$ heat-inactivated fetal calf serum, $2 \mathrm{mM}$ glutamine, $75 \mathrm{U} / \mathrm{ml}$ streptomycin, and $100 \mathrm{U} / \mathrm{ml}$ penicillin at $37^{\circ} \mathrm{C}, 5 \% \mathrm{CO}_{2}$ atmosphere. The cells were maintained in $\mathrm{T} 75$ tissue culture flasks and passaged every other day at a 1:5 dilution. The day before treatment the cells were split $1: 40$ into six-well plates in
}

complete media and returned to the incubator. The following day the cells were left untreated or treated with $10 \mathrm{nM}$ glucocorticoid by dilution of a sterile $10^{-5} \mathrm{M}$ stock solution of dexamethasone (Dex) in $\mathrm{dH}_{2} \mathrm{O}$ or $10^{-5} \mathrm{M}$ stock solution of cortisol or corticosterone in $\mathrm{EtOH} 100 \%$ (all steroids from Steraloids, $\mathrm{NH}$ ) and $24 \mathrm{~h}$ later the cells were induced to undergo apoptosis with either UV-C or FasL.

Apoptosis induction by UV-C. HTC cells in $3 \mathrm{ml}$ complete media were irradiated in six-well tissue culture plates or $35 \mathrm{~mm}$ glass bottom culture dishes (MatTek, Ashland, MA, USA). The tops of the tissue culture plates were removed to prevent shielding by the polystyrene. The plates containing the cells were placed in a Stratalinker (Stratagene) set for a $90 \mathrm{~mJ} / \mathrm{cm}^{2}$ dose of UV-C radiation which was achieved after $80 \mathrm{~s}$. Postirradiation the samples were returned to $37^{\circ} \mathrm{C}, 5 \% \mathrm{CO}_{2}$ atmosphere for further incubation.

Apoptosis induction with FasL. HTC cells in $3 \mathrm{ml}$ complete media were treated with $50 \mathrm{ng} / \mathrm{ml}$ FasL (Kamiya Biomedical, Seattle, WA, USA) and returned to $37^{\circ} \mathrm{C}, 5 \% \mathrm{CO}_{2}$ atmosphere. Both UV- and FasL-treated cells were analyzed after $24 \mathrm{~h}$ incubation. HTC cells at this dose of Fas ligand undergo apoptosis at a similar rate to the dose of UV-C described previously.

Microscopy. HTC cells were plated in $35 \mathrm{~mm}$ glass bottom culture dishes (MatTek, Ashland, MA, USA) and treated as described above. After $24 \mathrm{~h}$ of either UV-C, FasL, Dex, UV-C + Dex, FasL + Dex or no treatment HTC cells were visualized with a Zeiss 510 LSM-UV confocal microscope using DIC optics and a $\times 40$ oil objective. Multiple pictures were taken of each treatment group from three separate experiments and representative pictures were used in the final figure.

Whole cell protein extraction. Following experimental treatment cells were suspended in buffer containing $20 \mathrm{mM}$ TRIS, $2 \mathrm{mM}$ EDTA, $150 \mathrm{mM} \mathrm{NaCl}, 0.5 \%$ Triton X-100 and protease inhibitors (Complete Mini protease cocktail, Roche, IN USA) by pipeting. The cells were sonicated for $10 \mathrm{~s}$ on ice. A $5 \mu$ l sample of each lysate was assayed in a Beckman DU650 spectrophotometer for protein concentration using Biorad Protein Assay Reagent (Biorad Laboratories, CA, USA). Laemmli loading buffer containing glycerol, SDS, and bromphenol blue was added to each sample at a 1:1 ratio and then boiled for $5 \mathrm{~min}$. The samples were stored at $-80^{\circ} \mathrm{C}$ until electrophoresis and Western blot analysis for $\mathrm{Bcl}-\mathrm{x}_{\mathrm{L}}$ protein.

Subcellular Fractionation to separate mitochondrial and cytosolic proteins. Following experimental treatment cells were subjected to subcellular fractionation using a Mitochondrial/Cytosol Fractionation Kit (Biovision, Mountain View, CA, USA) following the manufacturer's recommended protocol. Treated and untreated cells $\left(5 \times 10^{7}\right)$ were collected by centrifugation at $600 \times g$ for $5 \mathrm{~min}$ at $4^{\circ} \mathrm{C}$. Cells were then washed with ice-cold PBS and centrifuged as above. The supernatant was discarded and the cells were resuspended in $1 \mathrm{ml}$ $1 \times$ cytosol extraction buffer with DTT and protease inhibitors (included in the kit) and incubated on ice for $10 \mathrm{~min}$. The cells were then homogenized with an ice-cold dounce tissue grinder (50 passes). The homogenate was centrifuged at $700 \times \mathrm{g}$ for $10 \mathrm{~min}$ at $4^{\circ} \mathrm{C}$ and supernatant collected (pellet discarded). The supernatant was then centrifuged at $10000 \times g$ for $30 \mathrm{~min}$ at $4^{\circ} \mathrm{C}$. The supernatant was collected as cytosolic fraction and the pellet resuspended in mitochondrial extraction buffer and vortexed for $10 \mathrm{~s}$ and collected as mitochondrial fraction. The protein concentration of each fraction was determined by the Biorad method described previously. After the protein concentration was determined the samples were mixed 1:1 with Laemmli loading buffer and boiled for $5 \mathrm{~min}$. The samples were then stored at $-80^{\circ} \mathrm{C}$ until assayed for $\mathrm{BCl}-\mathrm{X}_{\mathrm{L}}$ by Western blot.

Western blot analysis. Whole cell, mitochondrial or cytosolic protein lysates, $40 \mu \mathrm{g} / \mathrm{sample}$ were separated on $4-20 \%$ polyacrylamide tris $/$ glycine gels (Invitrogen, Grand Island, NY, USA) and transferred to nitrocellulose. After $2 \mathrm{~h}$ of blocking non-specific interactions with Tris-buffered saline (TBS) plus $0.5 \%$ Tween 20 with $10 \%$ Carnation nonfat-dry milk the membranes were incubated with primary antibodies to Bcl-- $\mathrm{K}_{\mathrm{L}}$, caspase 3 (Cell Signaling, Beverly, MA, USA) Mcl-1 (Trevigen, Gaithersburg, MD, USA) or Bid (Stratagene, La Jolla, CA, USA) and subsequently incubated with the appropriate secondary antibody (Amersham, Piscataway, NJ, USA), following the manufacturer's recommended protocol and visualized on film with the ECL chemiluminescent system (Amersham). The membranes were then stripped with buffer containing $2 \%$ SDS, $60 \mathrm{mM}$ TRIS and $\beta$-mercaptoethanol at $55^{\circ} \mathrm{C}$ for $30 \mathrm{~min}$, washed and reprobed with a monoclonal actin antibody (Chemicon, Temecula, CA, USA) or an $\alpha$-tubulin antibody (Sigma-Aldrich, MO, 
USA) as a control for equal loading. Cytochrome oxidase subunit IV antibody (Molecular Probes, Eugene, OR, USA) was used for mitochondrial fraction control.

Determination of change in cell size. Cell size and changes in the light scattering properties of the cells were determined by flow cytometry with a Becton Dickinson FACSort cytometer equipped with CellQuest software. ${ }^{41,42}$ In each sample 10000 cells were examined by exciting the cells with a $488 \mathrm{~nm}$ argon laser and by determining their distribution on a forward-scatter versus side-scatter dot plot. Light scattered in the forward direction is proportional to cell size, while light scattered at a $90^{\circ}$ angle (side scatter) is proportional to cell granularity. As a cell shrinks or loses cell volume, a decrease in the amount of forward-scattered light is observed along with a change in side-scattered light. Propidium iodide $(10 \mu \mathrm{g} / \mathrm{ml})$ was added as a determinant of viability. This dye does not enter cells with an intact plasma membrane. Therefore, gating on propidium iodide negative cells defines the viable population. Only these cells were used in analyzing cell size. The resulting data were converted to contour plots for presentation.

Mitochondrial membrane potential. Changes in the mitochondrial membrane potential $\left(\Delta \Psi_{\text {mito }}\right)$ were measured by flow cytometry using the mitochondrial potential dye, JC-1 (Molecular Probes, OR, USA). ${ }^{42,43}$ At 30 min prior to analysis, JC-1 was added to $1 \mathrm{ml}$ of cells (while vortexing) to a final concentration of $10 \mu \mathrm{M}$ and incubated at $37^{\circ} \mathrm{C}, 5 \% \mathrm{CO}_{2}$ atmosphere. $\mathrm{JC}-1$ has variable emission depending on the state of the mitochondrial membrane potential. JC-1 forms aggregates in mitochondria with normal $\Delta \Psi_{\text {mito }}$ and emits fluorescence in the orange range $(\sim 580 \mathrm{~nm})$. A decrease in the $\Delta \Psi_{\text {mito }}$ results in a reduction in orange fluorescence with a concurrent gain in green fluorescence $(\sim 520 \mathrm{~nm})$ as the dye shifts to a monomeric state. Loss of the dye in the mitochondria can be monitored through the increase in green fluorescence. Ten thousand cells per sample were analyzed and monomer versus aggregate fluorescence plots were used for subsequent analysis. Contour plots (aggregates versus monomers) were used for presentation.

DNA analysis. Cells were prepared for analysis of DNA content by slow addition of ice-cold $70 \%$ ethanol to $1 \times 10^{6}$ cells (final volume $5 \mathrm{ml}$ ) and stored overnight at $4^{\circ} \mathrm{C}$. Following fixation the cells were pelleted, washed one time with PBS, then stained with $1 \mathrm{ml}$ of $20 \mu \mathrm{g} / \mathrm{ml}$ propidium iodide, containing $1000 \mathrm{U}$ of RNase One (Promega) in $1 \times$ PBS for $20 \mathrm{~min}$. Cells were analyzed by flow cytometry on a FACSort cytometer (Becton-Dickinson) by gating on an area versus width dot plot to exclude debris and aggregates, and 10000 cells were examined on $585 \mathrm{~nm}$ fluorescence/area histogram. ${ }^{41}$ The percent of cells with degraded DNA was determined by the number of cells with subdiploid DNA divided by the total number of cells examined under each experimental condition.

Real-time PCR analysis. HTC cells were either treated for $24 \mathrm{~h}$ with $10 \mathrm{nM}$ Dex, $10 \mathrm{nM}$ Dex plus $100 \mathrm{nM}$ RU486 or left untreated. Total cellular RNA was isolated using RNeasy columns (QIAGEN, CA, USA). Isolated RNA content was determined at $260 \mathrm{~nm}$ and samples were stored at $-70^{\circ} \mathrm{C}$ until further use. Equal amounts of RNA for each sample were reverse-transcribed using an oligo $d(T)_{16}$ primer (ABI, CA, USA) and TaqMan ${ }^{\circledR}$ Reverse Transcription Reagents (ABI, CA USA). The CDNA was quantitated in a PCR reaction with Taq polymerase for 40 cycles with a denaturing step at $95^{\circ} \mathrm{C}$ for $15 \mathrm{~s}$ and an annealing/extension step at $60^{\circ} \mathrm{C}$ for $60 \mathrm{~s}$ performed on an $\mathrm{ABI} 7900$ real-time PCR machine. The forward primer for $\mathrm{rBCl}-\mathrm{x}_{\mathrm{L}}$ was GGGCACTGTGCGTGGAA and the reverse primer was TGGCCATCCAACTTGCAAT. The TaqMan TAMRA probe used was FAMAACAGGACACTTTTGTGGATCTCTACGGGAA-TAMRA. From the obtained $\mathrm{C}_{T}$ values a $\triangle \mathrm{C}_{\mathrm{T}}$ value for $\mathrm{rBcl}-\mathrm{x}_{\mathrm{L}}-\mathrm{rCyclophilin} \mathrm{B}$ (Assay-on-demand predeveloped primer/probe set, $A B I$ ) was calculated. The fold upregulation was calculated by comparing the $\Delta C_{T}$ of untreated cells to that of Dex or Dex plus RU486 treated HTC cells.

siRNA downregulation of $\mathrm{Bcl}-\mathrm{x}_{\mathrm{L}}$ protein. siRNA specific for rat $\mathrm{BCl}-\mathrm{X}_{\mathrm{L}}$ was generated by Dharmacon Inc. (Lafayette, CO, USA). The target sequence was AAAGCAUUCAGUGAUCUAACA, the sense sequence was AGCAUUCAGUGAUCUAACAdTdT, and the antisense was UGUUAGAUCACUGAAUGCUdTdT. A non-specific negative control RNA (BLAST searches verified that it contained no homology to any known motifs) was also obtained from Ambion (Austin, TX, USA). A confluent T75 flask of HTC cells was split 1:20 into six-well plates. The next day the media was changed to Optimem (Invitrogen-Gibco, CA, USA) with no additives and the cells transfected with siRNA for $\mathrm{Bcl}-\mathrm{x}_{\mathrm{L}}$, negative control or no RNA using Metafectene (Biontex, Munich, Germany). After $4 \mathrm{~h}$ the cells were returned to complete media. The third day the cells were treated with hormone and the fourth day UV-C irradiated (always one plate of cells left non-treated for controls). On the fifth day the cells were harvested for analysis by flow cytometry and western blotting as previously described.

Acknowledgements. We gratefully acknowledge the expert advice of $\mathrm{Dr}$ Carl Bortner (flow cytometry) and Dr JoLyn Turner (microscopy) and Drs Elizabeth Murphy, William Schrader and Kenneth Korach for reviewing the manuscript. This research was supported by the Intramural Research Program of the NIH, National Institute of Environmental Health Sciences.

1. Reed JC (1999) Dysregulation of apoptosis in cancer. J Clin Oncol 17: 2941-2950.

2. McKay LI, Cidlowski JA (2003) Corticosteroids. In Kufe DW et al. (ed). Cancer Medicine 6. BC Decker Inc.: Hamilton, 927-938.

3. Gorman AM, Hirt UA, Orrenius S, Ceccatelli S (2000) Dexamethasone pre-treatment interferes with apoptotic death in glioma cells. Neuroscience 96: 417-425.

4. Pagliacci MC, Migliorati G, Smacchia M, Grignani F, Riccardi C, Nicoletti I (1993) Cellular stress and glucocorticoid hormones protect L929 mouse fibroblasts from tumor necrosis factor alpha cytotoxicity. J Endocrinol Invest 16: 591-599.

5. Hammer S, Sauer B, Spika I, Schraut C, Kleuser B, Schafer-Korting M (2004) Glucocorticoids mediate differential anti-apoptotic effects in human fibroblast and keratinocytes via shingosine-1-phosphate formation. J Cell Biochem 91: 840-851.

6. Schorr K, Furth PA (2000) Induction of bcl-xL expression in mammary epithelial cells is glucocorticoid-dependent but not signal transducer and activator of transcription 5dependent. Cancer Res 60: 5950-5953.

7. Moran TJ, Gray S, Mikos CA, Conzen SD (2000) The glucocorticoid receptor mediates a survival signal in human mammary epithelial cells. Cancer Res 60: 867-872.

8. Yamamoto M, Fukuda K, Miura N, Suzuki R, Kido T, Komatsu Y (1998) Inhibition by dexamethasone of transforming growth factor $B 1$-induced apoptosis in rat hepatoma cells: a possible association with Bcl-xl induction. Hepatology 27: 959-966.

9. Messmer UK, Winkel G, Briner VA, Pfeilschifter J (2000) Suppression of apoptosis by glucocorticoids in glomerular endothelial cells: effects on proapoptotic pathways. $\mathrm{Br} \mathrm{J}$ Pharmacol 129: 1673-1683.

10. Evans-Storms RB, Cidlowski JA (2000) Delineation of an antiapoptotic action of glucocorticoids in hepatoma cells: the role of nuclear factor-kB. Endocrinol 141: 18541862.

11. Zimmermann KC, Green DR (2001) How cells die: apoptosis pathways. J Allergy Clin Immunol 108: S99-103.

12. Kischkel FC, Hellbardt S, Behrmann I, Germer M, Pawlita M, Krammer PH et al. (1995) Cytotoxicity-dependent APO-1 (Fas/CD95)-associated proteins form a death-inducing signaling complex (DISC) with the receptor. EMBO J 14: 5579-5588.

13. Medema JP, Scaffidi C, Kischkel FC, Shevchenko A, Peter ME (1997) FLICE is activated by association with the CD95 death-inducing signaling complex (DISC). EMBO J 16: 27942804.

14. Li H, Zhu H, Xu C-J, Yuan J (1998) Cleavage of BID by caspase 8 mediates the mitochondrial damage in the Fas pathway of apoptosis. Cell 94: 491-501.

15. Scaffidi C, Fulda S, Srinivasan A, Friesen C, Li F, Tomaselli KJ et al. (1998) Two CD95 (APO-1/Fas) signaling pathways. EMBO J 17: 1675-1687.

16. Fumarola C, Guidotti GG (2004) Stress-induced apoptosis: toward a symmetry with receptor-mediated cell death. Apoptosis 9: 77-82.

17. Kroemer G, Zamzami N, Susin SA (1997) Mitochondrial control of apoptosis. Immunol Today 18: 44-51

18. Zou H, Henzel WJ, Liu X, Lutschg A, Wang X (1997) Apaf-1, a human protein homologous to $C$. elegans CED-4 participates in cytochrome $c$-dependent activation of caspase-3. Cell 90: $405-413$

19. Kluck RM, Bossy-Wetzel E, Green DR, Newmeyer DD (1997) The release of cytochrome $c$ from mitochondria: a primary site for Bcl-2 regulation of apoptosis. Science 275: 11321136.

20. Li P, Nijhawan D, Brudihardjo I, Srinivasula SM, Ahnad M, Alnemri ES et al. (1997) Cytochrome $C$ and dATP-dependent formation of Apaf-1/caspase9 complex initiates an apoptotic protease cascade. Cell 91: 479-489.

21. Cecconi F, Alvarez-Bolado G, Meyer BI, Roth KA, Gruss P (1998) Apaf1 (CED-4 Homolog) regulates programmed cell death in mammalian development. Cell 94: 727-737.

22. Green DR (1998) Apoptotic pathways: the roads to ruin. Cell 94: 695-698.

23. Lotem J, Sachs $L$ (1995) Regulation of BCl-2, Bcl-xl and BAX in the control of apoptosis by hematopoietic cytokines and dexamethasone. Cell Growth Differ 6: 647-653.

24. Pecci A, Viegas LR, Baranao JL, Beato M (2001) Promoter choice influences alternative splicing and determines the balance of isoforms expressed from the mouse Bcl-x gene. J Biol Chem 276: 21062-21069. 
25. Gascoyne DM, Kypta RM, Vivanco MdM (2003) Glucocorticoids inhibit apoptosis during fibrosarcoma development by transcriptionally activating Bcl-xl. J Biol Chem 278: 1802218029.

26. Vu CCQ, Bortner CD, Cidlowski JA (2001) Differential involvement of initiator caspases in apoptotic volume decrease and potassium efflux during Fas- and UV-induced cell death. J Biol Chem 276: 37602-37611.

27. Zucchini N, de Sousa G, Bailly-Maitre B, Gugenheim J, Bars R, Lemaire G et al. (2005) Regulation of $\mathrm{Bcl}-2$ and $\mathrm{Bcl}-\mathrm{xL}$ anti-apoptotic protein expression by nuclear receptor $\mathrm{PXR}$ in primary cultures of human and rat hepatocytes. Biochim Biophys Acta 1745: 48-58.

28. Sakamoto T, Repasky WT, Chen J, Hirata A, Hirata F (1995) Down-regulation of Bcl-xs gene expression in rat thymocytes by dexamethasone. Biochem Biophys Res Comm 215 511-516.

29. Viegas LR, Vicent GP, Baranao JL, Beato M (2004) Steroid hormones induce Bcl-x gene expression through direct activation of distal promoter P4. J Biol Chem 279: 9831-9839.

30. Mikosz CA, Brickley DR, Sharkey MS, Moran TW, Conzen SD (2001) Glucocorticoid receptor-mediated protection from apoptosis is associated with induction of the serin threonine survival kinase gene, skg-1. J Biol Chem 276: 16649-16654.

31. Wu W, Chaudhuri S, Brickley DR, Pang D, Karrison T, Conzen SD (2004) Microarray analysis reveals glucocorticoid-regulated survival genes that are associated with inhibition of apoptosis in breast epithelial cells. Cancer Res 64: 1757-1764.

32. Wen LP, Madani K, Fahrni JA, Duncan SR, Rosen GD (1997) Dexamethasone inhibits lung epithelial cell apoptosis induce by IFN-gamma and Fas. Am J Physiol 273: L921-L929.

33. Webster JC, Huber RM, Hanson RL, Collier PM, Haws TF, Mills JK et al. (2002) Dexamethasone and tumor necrosis factor- $\alpha$ act together to induce the cellular inhibitor of apoptosis-2 gene and prevent apoptosis in a variety of cell types. Endocrinol 143: 38663874.
34. Chan S-L, Yu VC (2004) Proteins of the Bcl-2 family in apoptosis signalling: from mechanistic insights to therapeutic opportunities. Clin Exp Pharmacol Physiol 31 119-128.

35. Oh H-Y, Namkoong S, Lee S-J, Por E, Kim C-K, Billiar TR et al. (2006) Dexamethasone protects primary cultured hepatocytes from death receptor-mediated apoptosis by upregulation of CFLIP. Cell Death Differ 13: 512-523.

36. Herr I, Pfitzenmaier J (2006) Glucocorticoid use in prostate cancer and other solid tumours: implications for effectiveness of cytotoxic treatment and metastases. Lancet Oncol 7 425-430.

37. Sui M, Chen F, Chen Z, Fan W (2006) Glucocorticoids interfere with therapeutic efficacy of paclitaxel against human breast and ovarian xenograft tumors. Int J Cancer 119: 712-717.

38. Yerramasetti R, Gollapudi S, Gupta S (2002) Rifampicin inhibits CD95-mediated apoptosis of jurkat $T$ cells via glucocorticoid receptors by modifying the expression of molecules regulating apoptosis. J Clin Immunol 22: 37-47.

39. Ray DW, Lovering AM, Davis JRE, White A (1998) Rifampicin: a glucocorticoid receptor ligand? Nat Med 4: 1090

40. Takehara T, Liu X, Fujimoto J, Friedman SL, Takahashi H (2001) Expression and role of $\mathrm{Bcl}-\mathrm{xL}$ in human hepatocellular carcinomas. Hepatology 34: 55-61.

41. Bortner CD, Cidlowski JA (1996) Absence of volume regulatory mechanisms contributes to the rapid activation of apoptosis in thymocytes. Am J Physiol 271: C950-C961.

42. Scoltock AB, Cidlowski JA (2004) Activation of intrinsic and extrinsic pathways in apoptotic signaling during UV-C-induced death of Jurkat cells: the role of caspase inhibition. Exp Cell Res 297: 212-223.

43. Bortner CD, Cidlowski JA (1999) Caspase independent/dependent regulation of $\mathrm{K}_{+}$, cell shrinkage, and mitochondrial membrane potential during lymphocyte apoptosis. $J$ Biol Chem 274: 21953-21962.

Supplementary Information accompanies the paper on Cell Death and Differentiation website (http://www.nature.com/cdd) 